\title{
Comparison of number and shape of parr marks in three species of the genus Salmo and two ecotypes of cultured brown trout Salmo trutta from Turkey
}

\author{
M. KOCABAS ${ }^{1}$, N. BASCINAR ${ }^{2}$ AND F. KUTLUYER ${ }^{3}$ \\ ${ }^{1}$ Karadeniz Technical University, Faculty of Forestry, Department of Wildlife Ecology and Management \\ 61080, Trabzon, Turkey \\ ${ }^{2}$ Karadeniz Technical University, Faculty of Marine Sciences, Department of Fisheries Technology Engineering \\ 61530, Trabzon, Turkey \\ ${ }^{3}$ Tunceli University, Fisheries Faculty, 62000, Tunceli, Turkey \\ e-mail:filizkutluyer@hotmail.com.tr,mkocabas@gmail.com
}

\begin{abstract}
This study focused on the variation in number and shape of parr marks in three fish species of the genus Salmo [S. abanticus Tortonese, (1954), S. caspius Kessler, (1877) and S. labrax Pallas, (1814)] and two ecotypes of cultured brown trout [S. trutta macrostigma (Dumeril, 1858) and S. trutta fario Linnaeus, (1758)]. The brown trouts were collected from 11 streams in Turkey by electrofishing and transferred to the laboratory in an aerated container and then stocked in the adaptation tanks. Artificially fertilized eggs were incubated and larvae were maintained in fiberglass tanks and the variations in number and shape of parr marks in all five groups were studied for one year. The data collected indicated that there were significant differences in the number and size (length and width) of parr marks among the groups $(\mathrm{p}<0.05)$. The highest number of parr marks (11-13) was recorded in S. trutta macrostigma. Parr marks on the skin of S. trutta. macrostigma was found to remain stable during development.
\end{abstract}

Keywords: Brown trout, Ecotypes, Parr marks, S. abanticus, S. caspius, S. labrax, S. trutta macrostigma, S. trutta fario

Brown trouts (Salmo trutta and related species) are important fishes having aquaculture potential, economic value and wide consumer demand. Brown trouts forms resident populations in the upper streams of rivers in North Africa, Europe, West Asia and Anatolia (Kuru, 2004; Kottelat et al., 2007) and are also important species of recreational fishery. Three species of brown trouts namely Salmo abanticus Tortonese, (1954), Salmo caspius Kessler, (1877) and Salmo labrax Pallas, (1814) and two ecotypes of Salmo trutta [S. trutta macrostigma Dumeril, (1858) and $S$. trutta fario Linnaeus, (1758)] are cultured in Turkey (Kocabas, 2009).

Spots pattern and colouration characteristics are primarily used for identification of species or different strains within a population (Skaala and Jorstad, 1988; Largiader and Scholl, 1996; Lascaux, 1996; Aparicio et al., 2005) and often varies in different populations (Blanc et al., 1982, 1994; Moran et al., 1989; Mezzera et al., 1997).

Parr marks are important phenotypic traits in salmonid species, present as, series of distinctive vertical dark bands along the sides of the body especially in the younger groups. These marks may serve as camouflage in vulnerable young fishes (Venkataraman, 2011). Parr marks may persist in young adults, but disappear in adults. Visible parr marks are important characteristics in several fishes for identification (Aparicio et al., 2005). Brown trout juveniles normally have visible parr marks on their sides as in many other salmonid species (Mezzera et al., 1997). Parr growth rate, shape and parr mark pigmentation show differences among different populations (Culling et al., 2013).

The objective of this study was to examine duration of the parr marks formation and to determine the differences in parr mark number and size (length and width) in different species/ecotypes of brown trouts from Turkey.

Adult individuals of trouts ( $S$. abanticus, S. trutta macrostigma, S. caspius, S. trutta fario and S. labrax) were collected by electrofishing from 11 streams in Turkey (after availing permission from Ministry of Agriculture and Rural Affairs, General Directorate of Protection and Control). The fishes were transferred to the laboratory in aerated containers and stocked in adaptation pools at Black Sea Technical University Scientific Research Foundation, Trabzon. For each fish, total weight (g) and fork length $(\mathrm{mm})$ were measured, recorded and tagged using Visible Implant Fluorescent Elastomer tags. The fishes were bred in captivity and the larvae were maintained 
in fiberglass tanks $(40 \times 50 \times 50 \mathrm{~cm})$ with recirculation facility. Daily average water exchange was only $20 \%$. Temperature was measured with a digital thermometer two times a day at (8:00-9:00 and 16:00-17:00 hrs). Temperature of the incoming water was $10.2 \pm 1.08^{\circ} \mathrm{C}$ ( 7.7 to $14.2^{\circ} \mathrm{C}$ ). All groups were fed daily the same ration of commercial feed with automatic feeders. Number and shape of parr marks were examined in all the five groups when the larvae reached size range of 3.5 to $4.5 \mathrm{~cm}$ [S. abanticus $(\mathrm{n}=41), S$. trutta macrostigma $(\mathrm{n}=20)$, S. aspius $(\mathrm{n}=25)$, S. t. fario $(\mathrm{n}=21)$ and S. labrax $(\mathrm{n}=16)]$. The fishes were anaesthetised using benzocaine solution (30 $\mathrm{mg} \mathrm{l}^{-1}$ ) and measured fork length (LF) to the nearest $\mathrm{mm}$ and were photographed with a digital camera (Sony DSC-W350). Visible parr marks were counted in all fishes. Size (width and length) of parrmarks were measured or identified from the photographs.

Differences in parr marks number and size on all the five groups were tested using one-way ANOVA. Statistical analyses were performed with SPSS 14.0 software package. Duncan's multiple range test was used for all post-hoc comparisons.

The mean length and weight of all five groups studied (S. abanticus, S. trutta macrostigma, S. caspius, S. trutta fario and $S$. labrax) were $51.69 \pm 13.54 \mathrm{~mm}$ and $1.63 \pm 1.53 \mathrm{~g} ; 89.72 \pm 54.97 \mathrm{~mm}$ and $16.98 \pm 23.00 \mathrm{~g}$; $43.72 \pm 25.25 \mathrm{~mm}$ and $2.52 \pm 7.64 \mathrm{~g} ; 52.94 \pm 11.72 \mathrm{~mm}$ and $1.93 \pm 1.46 \mathrm{~g} ; 59.81 \pm 26.58 \mathrm{~mm}$ and $3.79 \pm 5.11 \mathrm{~g}$, respectively.

Table 1. Number (Mean \pm SE) of parr marks in Salmo spp. and S. trutta ecotypes

\begin{tabular}{lllll}
\hline Species/ Ecotype & $\mathrm{n}$ & Mean $\pm \mathrm{SD}(\min -\max )$ & $\mathrm{F}$ & $\mathrm{P}$ \\
\hline S. trutta macrostigma & 20 & $11 \pm 1^{\mathrm{a}}(10-12)$ & & \\
S. abanticus & 41 & $6 \pm 1^{\mathrm{b}}(4-7)$ & & \\
S. trutta fario & 25 & $5 \pm 1^{\mathrm{c}}(5-7)$ & 115.23 & 0.000 \\
S. caspius & 21 & $8 \pm 1^{\mathrm{d}}(7-9)$ & & \\
S. labrax & 16 & $8 \pm 1^{\mathrm{d}}(7-9)$ & & \\
\hline
\end{tabular}

Skin pigmentation pattern and the numbers of parr marks are presented in Fig. 1 and Table 1. There were significant differences in parr marks number among the five groups of juvenile brown trouts $(p<0.05)$. The highest mean number of parr marks was in S. trutta macrostigma population $(11 \pm 1)$ while the lowest number was in the $S$. trutta fario population $(5 \pm 1)$.

VisibleparrmarksinS.abanticus,S.truttamacrostigma, S. caspius, $S$. trutta fario and S. labrax were initially observed from length groups $40 \pm 10 \mathrm{mcm}, 50 \pm 30 \mathrm{~mm}$, $25 \pm 20 \mathrm{~mm}, 4 \pm 40 \mathrm{~mm}$ and $36 \pm 20 \mathrm{~mm}$, respectively (Table 2). Parr marks were more distinctive in $S$. trutta macrostigma. Parr marks completely formed on each side of $S$. trutta fario on reaching $100 \mathrm{~mm}$ length.

The relationships between the length and width of parr marks are given in Table 2. Significant differences were obtained from the statistical comparison in length and width of parr marks between all groups tested $(p<0.05)$. Size of parr marks positively correlated with growth in all the five groups. Largest parr mark was observed in S. trutta macrostigma population and the smallest in $S$. caspius population.

Detailed identification and classifications differentiate species into subspecies, sub-population (Wells and Richmond, 1995), distinct population segments (US Fish and Wildlife Service, 1973), evolutionarily significant units (Ryder, 1986), evolutionary units (Committee on scientific issues in the endangered species act, 1995) and designatable units (DUs; COSEWIC, 2010). In recent years, the importance of ecotypes was emphasised by Morrison (2012) to identify the differences in morphology, physiology, behaviour, geographic range separation, phylogenetic divergence, local adaptations for ecological settings, genetics (COSEWIC, 2010) and also to reflect fundamental differences in life history characters (Pond et al., 2016). Particularly, brown trout (S. trutta) shows a wide range of diversity in morphological characters.

Table 2. Length and width (Mean \pm SE) of parr marks of Salmo spp. and S. trutta ecotypes

\begin{tabular}{llllll}
\hline Species/Ecotypes & S. abanticus & S. trutta macrostigma & S. caspius & S. trutta fario & S. labrax \\
\hline LF & & & & & \\
$\begin{array}{l}\text { Mean } \pm \text { SD } \\
\text { (min-max) }\end{array}$ & $51.30 \pm 13.51^{\text {bc }}$ & $89.53 \pm 55.11^{\mathrm{a}}$ & $43.27 \pm 25.16^{\mathrm{c}}$ & $52.43 \pm 11.80^{\mathrm{bc}}$ & $59.57 \pm 26.52^{\mathrm{b}}$ \\
PW & $31.00-87.00$ & $40.00-193.00$ & $26.00-150.00$ & $37.00-77.00$ & $36.00-118.00$ \\
Mean \pm SD & & & & \\
(min-max) & $1.88 \pm 0.48^{\text {cd }}$ & $3.45 \pm 2.63^{\mathrm{a}}$ & $1.59 \pm 0.79^{\mathrm{d}}$ & $2.09 \pm 0.73^{\mathrm{c}}$ & $2.69 \pm 1.63^{\mathrm{b}}$ \\
PL & $0.85-2.93$ & $1.24-9.23$ & $0.63-4.44$ & $0.97-3.54$ & $1.24-6.48$ \\
$\begin{array}{l}\text { Mean } \pm \text { SD } \\
\text { (min-max) }\end{array}$ & $3.77 \pm 0.92^{\mathrm{b}}$ & $6.29 \pm 4.06^{\mathrm{a}}$ & & & \\
\hline
\end{tabular}

LF: Fork length (mm), PL: Parr mark length (mm), PW: Parr mark width (mm) 


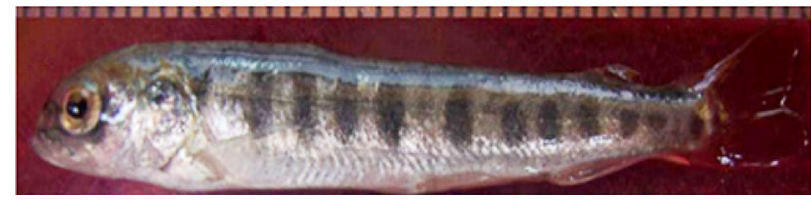

(a)

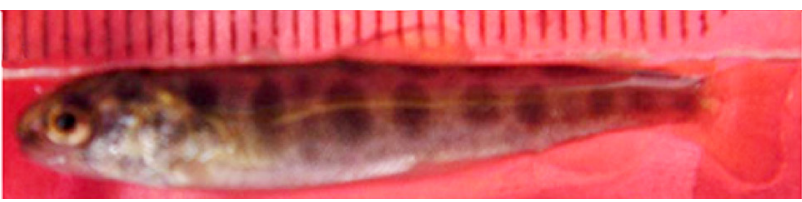

(c)

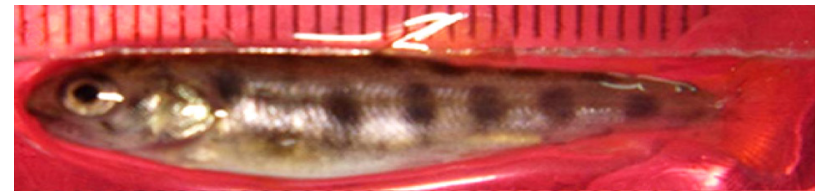

(b)

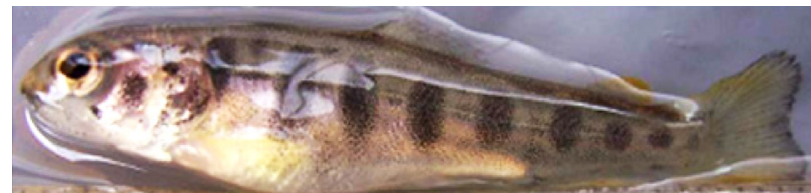

(d)

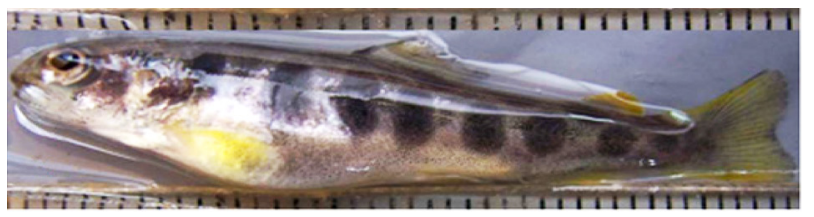

(e)

Fig. 1. Skin pigmentation pattern and parr marks of three species of trouts and two ecotypes of $S$. trutta; (a) $S$. trutta macrostigma (L=44.82 mm), (b) S. caspius (L=37.67 mm), (c) S. abanticus (L=39.48 mm), (d) S. trutta fario (L=41.89 mm), (e) S. labrax (L=36.20 mm)

S. trutta was represented by five ecotypes in Turkey but current consensus on classification and taxonomy retained the species status of three, namely $S$. abanticus, S. caspius and $S$. labrax. In the current scenario, the present study analysed characteristics and formation of parr marks in all five groups of brown trout from Turkey. It was confirmed that the number, size, and formation of parr marks differed in all the groups studied. The parr marks were stable in $S$. trutta macrostigma while they diminished in other groups with growth.

Only a few studies concentrated on the relationship of parr marks and spots pattern in salmonids. Venkataraman, (2011) opined that the parr marks of members of the Salmonidae disappear shortly after the juvenile phase and the parr mark development in the river resident form of the red spotted masu trout (Oncorhynchus masou ishikawae) was completed relatively early in the life cycle of fish (6 to 7 months after hatching) and remained stable during further development. Aparicio et al. (2005) stated that parr marks may persist into young adults, but disappear in large individuals. Kurtoglu (2002) reported that parr marks diminished in S. trutta fario and S. trutta labrax after smoltification. In the present study, the results indicated that parr marks diminished in S. abanticus, S. caspius, S. trutta fario and S. labrax with growth but they were constant in S. trutta macrostigma. These morphological differentiations could be due to genetic drift in populations (Karaiskou et al., 2009).

Mezzera et al. (1997) reported that the number of parr marks were between 11 and 13 in S. trutta but according to Aparicio et al. (2005) it ranged between 8 and 12 . The present study recorded 5 to 12 parr marks in all five groups. The noted difference in number of parr marks may be due to differences in physiology or genetic relation with local adaptation and heterogeneous environmental conditions (Pond et al., 2016).

Number of parr marks may increase (Martinez, 1984) or remain unchanged with increasing fork length (Mezzera et al., 1997). The results confirm the observations of Mezzera et al. (1997) that the length and width of parr marks increased with length or size of the fish. In conclusion, all five groups of cultured brown trouts showed distinct variation in the morphological traits which can help in identification and segregation even at the juvenile stage. Parr marks can be used as a character to distinguish all the five groups from $30 \mathrm{~mm}$ size onwards.

\section{References}

Aparicio, E., Garcia-Berthou, E., Araguas, R. M., Martinez, P. and Garcia-Marin, J. L. 2005. Body pigmentation pattern to assess introgression by hatchery stocks in native Salmo trutta from Mediterranean streams. J. Fish Biol., 67(4): 931-949.

Blanc, J. M., Poisson, H. and Vibert, R. 1982. Variabilite ge'ne'tique de la ponctuation noire sur la truitelle Fario (Salmo trutta L.). Ann. Genet. Sel. Anim., 14(2): 225-236.

Blanc, J. M., Chevassus, B. and Krieg, F. 1994. Inheritance of the number of red spots on the skin of the brown trout. Aquat. Living Resour., 7(2): 133-136. 
Committee on cientific issues in the endangered epecies act 1995. Science and the endangered species act. National Research Council, Washington, D.C.

COSEWIC 2010. Committee on the status of wildlife in Canada 2010, Guidelines for recognising designatable units (20 September $2015 \mathrm{http}: / /$ www.cosewic.gc.ca/eng/sct2/ sct2_5_e.cfm (Accessed 20 September 2015).

Culling, M., Freamo, H., Patterson, K., Berg, P. R., Lien, S. and Boulding, E. G. 2013. Signatures of selection on growth, shape, parr marks and SNPs among seven Canadian Atlantic Salmon (Salmo Salar) populations. Open Evol. J., 7: 1-16.

Karaiskou, N., Triantafyllidis, A., Katsares, V., Abatzopoulos, T. J. and Triantaphyllidis, C. 2009. Microsatellite variability of wild and farmed populations of Sparus aurata. J. Fish Biol., 74: 1816-1825.

Kocabas, M. 2009. Comparasion of growth performance and morphologic characteristics of brown trout (Salmo trutta) ecotypes of Turkey. Ph. D. thesis Karadeniz Teknik Universitesi, Fen Bilimleri Enstitusu, Trabzon, Turkey.

Kottelat, M. and Freyhof, J. 2007. Handbook of European freshwater fishes. Kottelat, Cornol, Switzerland and Freyhof, Berlin, Germany, 646 pp.

Kurtoglu, I. Z. 2002. Evaluation of brown trout (Salmo trutta labrax, L.) production under intensive culture condition and determination of its ranching potentials. $\mathrm{Ph}$. D. Thesis. Istanbul University, Institute of Science and Technology, Istanbul, Turkey.

Kuru, M. 2004. The last systematic status of inland fish in Turkey. G UJ. Fac. Educ., 24(3): 1-21.

Largiader, C. R. and Scholl, A. 1996. Genetic introgression between native and introduced brown trout (Salmo trutta L.) populations in the Rhone River basin. Mol. Ecol., 5(3): 417-426.
Lascaux, J. M. 1996. Analyse de la variabilite' morphologique de la truite commune (Salmo trutta L.) dans les cours d'eau du basin pyre'ne'en me'diterrane'en. Ph. D. Thesis, Ecole Nationale Supe'rieure Agronomique de Tolouse, Toulouse, France.

Martinez, A. 1984. Identification of brook, brown, rainbow and cutthroat trout larvae. Trans. Am. Fish. Soc., 113(2): 252-259.

Mezzera, M., Largiader, C. R. and Scholl, A. 1997. Discrimination of native and introduced brown trout in the River Doubs (Rhone drainage) by number and shape of parr marks. J. Fish Biol., 50(3): 672-677.

Moran, P., Pendas, A. M., Garcia-Vazquez, E., Linde, A. R. 1989. Chromosomal and morphological analysis of two populations of Salmo trutta fario employed in repopulation. J. Fish Biol., 35(6): 839-843.

Morrison, M. L. 2012. The habitat sampling and analysis paradigm has limited value in animal conservation: a prequel. J. Wildl. Manage., 76: 438-450.

Pond, B. A., Brown, G. S., Wilson, K. S. and Schaefer, J. A. 2016. Drawing lines: Spatial behaviours reveal two ecotypes of woodland caribou. Biol. Conserv., 194: 139-148.

Ryder, O. A. 1986. Species conservation and systematics: the dilemma of subspecies. Trends Ecol. Evolut., 1: 9-10.

Skaala, O. and Jorstad, K. E. 1988. Inheritance of the fine-spotted pigmentation pattern of brown trout. Pol. Arch. Hydrobiol., 35: 295-304.

Venkataraman, C. 2011. Modeling parr mark pattern formation during the early development of Amago trout. Phys. Rev. E., 84: 041923 .

Wells, J. V. and Richmond, M. E. 1995. Populations, metapopulations and species populations: what are they and who should care? Wildlife Soc. B., 23: 458-462. 